\title{
TRTaKadeMi
}

ISSN 2149-9446 | Cilt 06 | Sayı 12 | Mayıs 2021 | Dijital Hayat ve Etik

\section{Dijital Medyada Programatik Reklamcllık ve Etik Sorunlar}

\section{Mevlüt Hürol METE*}

\begin{abstract}
Öz
Dijital medyanın önlenemez gelişimi ile birlikte reklamcılık sektöründe de köklü değişiklikler meydana gelmiştir. Dijital tüketici kavramının ortaya çıkması tüketici davranışlarını değiştirmiş ve sektörü bu yeni düzene adapte olmaya itmiştir. Şüphesiz sektörün büyümesi, geleneksel oyuncuların yanına yeni rakipler getirmiş ve bu yıkıcı rekabet içerisinde hayatta kalmak isteyen firmalar için tüketici verileri çok değerli hâle gelmiştir. Bu noktada programatik reklamcılık gibi veriye ve otomasyona dayalı sistemler ön plana çıkmış ve firmalar açısından cezbedici olmuştur. Mevcut veya potansiyel tüketici verilerine erişim konusu etik sorunları da beraberinde getirmiştir. Bu noktada kişisel verilerin kullanımından kaynaklı etik sorunlar, gizlilik ihlalleri konusunda açık ve şeffaf kurallar konulması gerekli hâle gelmiştir. Bu çalışmada dijital medyanın pazarlama alanına getirdiği yenilikler ele alınarak son dönemde oldukça ön plana çıkan programatik reklamcılık konusuna yer verilecektir. Büyük verinin kullanılmasını odağına alan bu yeni reklam türünün sektörü nasıl dönüştürdüğü incelenerek kişisel verilerin kullanımı ve gizlilik ihlalleri ile ilgili etik konular çerçevesinde değerlendirilecektir. Konuyla ilgili yapılan araştırmalar sektördeki yenilikçi uygulamalar ile kullanıcıların algıları arasında büyük bir çelişkiler bulunduğunu göstermektedir. Bu çalışma kapsamında uluslararası araştırmalar tarama yöntemiyle derlenerek, yeni medyanın reklamcılık sektörüne getirdiği karmaşık süreçler ile günlük hayatımızda karşımıza çıkan etik sorunlar örneklerle ele alınacaktır.
\end{abstract}

Anahtar Kelimeler: Programatik Reklamcılık, Yeni Medya, Veri Gizliliği, Reklam ve Etik, Dijital Pazarlama

*Dr., hurolmete@gmail.com

\section{Derleme Makale}

Geliş Tarihi: 08.02.2021

Kabul Tarihi: 24.05.2021

ORCID ID: 0000-0002-7288-3434 DOI: 10.37679/trta.876044 


\title{
TRTAKaDeMi
}

ISSN 2149-9446 | Volume 06 | Issue 12 | May 2021 |Digital Life and Ethics

\section{Programmatic Advertising and Ethical Issues in Digital Media}

\section{Mevlüt Hürol METE}

\begin{abstract}
With the inevitable development of digital media, radical changes have occurred in the advertising industry. The emergence of the digital consumer concept has changed consumer behavior and pushed the industry to adapt to this new system. Undoubtedly, the growth of the sector has brought new competitors to traditional players and consumer data has become very valuable for companies that want to survive in this destructive competition. At this point, systems based on data and automation such as programmatic advertising came to the fore and became attractive for companies. Access to existing or potential consumer data has brought ethical issues with it. At this point, it has become necessary to establish clear and transparent rules regarding ethical problems and privacy violations arising from the use of personal data. In this study, the innovations brought by digital media to the field of marketing will be discussed and the subject of programmatic advertising, which has come to the forefront recently. How this new type of advertising, which focuses on the use of big data, transforms the sector will be examined and evaluated within the framework of ethical issues related to the use of personal data and privacy violations. Studies on the subject show that there is a great contradiction between innovative applications in the sector and the perceptions of users. Within the scope of this study, international researches will be compiled by screening method, and the complex processes that new media bring to the advertising industry and the ethical problems we face in our daily lives will be discussed with examples.
\end{abstract}

Keywords: Programmatic Advertising, New Media, Data Privacy, Advertising and Ethics, Digital Marketing

Review Paper

Recieved: 08.02.2021

Accepted: 24.05.2021 


\section{Giriş}

Dijital medya, insanları yeni bir siber dünyanın parçası yapmıştır. Sürekli çevrim içi ve etkileşimde olmamızı sağlayan dijital medya araçları hayatın her alanına dokunduğu için reklamcılık alanına da yadsınamaz değişiklikler getirmiştir. Veriye dayalı pazarlama otomasyonu artık dijital pazarlama endüstrisinin vazgeçilmez bir unsuru hâline gelmiştir. Bu kapsamda yeni medya reklamcılığına köklü bir değişim getiren programatik reklamcılık, sektörü derinden etkilemiş, her reklam formatının programlı olarak uygulanabileceği yeni bir tür ortaya çıkmıştır. Ayrıca otomasyon yoluyla kişisel, yerel ve gerçek zamanlı reklam yaparak reklam kavramını birçok yönden değiştiren bir çözüm olmuştur.

Geleneksel reklamcılık, işletmelerin sadece satışa odaklandığı ve daha fazla satış yapmak için daha fazla iletişime ihtiyaç duyduğu dönemlere ait bir kavramdır. Buna göre reklam verirken aynı anda çok sayıda izleyiciye tek bir mesajı iletmek için geleneksel medya araçları kullanılmıştır. Geleneksel reklamcılık yaklaşımında reklamlar, tüketiciyi pasif olarak ürün hakkında bilgilendirmek için doğrusal bir sunum olarak tasarlanmış, hedef kitlenin dikkatini sınırlı bir alanda tutmaya çalışmıştır. Ancak yeni medyanın yaygınlaşmasıyla reklamcılık sektörü da bu yeni alanlara göre şekillenmiştir.

Programatik reklamcılık, gerçek zamanlı fiyatlandırma ve teklif vermeyi içeren hedef kitlelere derinlemesine kişiselleştirilmiş pazarlama materyallerini yaymak için büyük veri kümelerini kullanan nispeten yeni bir bilişim uygulamasıdır (White ve Samuel, 2019) ve programatik reklamcılık konusu firmaların yanı sıra, politika yapıcılar ve araştırmacılar için giderek daha önemli hâle gelmektedir. Programatik reklamcılığın dili, insanların "mikro anlarını" anlamaya ve bu anları etkilemeye çalışmaktır.

Reklam sahtekârlığı, botnet'ler ve hatta gerçek insanların mı yoksa makinelerin mi reklamlara tikladığına dair sorular olsa da programatik reklamın temelini oluşturan mantık oldukça güçlüdür. Hayatımızın tüm bağlamını haritalandırmayı amaçladığı ve tam olarak doğru anda bilgi ve duygusal alaka düzeyi aradığı için bir dizi özelliğe sahiptir." (McStay, 2017).

Yapılan araştırmalar insanların, kendilerini korumak konusunda tutarsız ve çelişkili dürtüleri olduğunu yani bir tür gizlilik paradoksu içerisinde olduklarını göstermektedir (Watts, 2016). Başka bir deyişle, gizlilik artık bir sosyal norm olmaktan çıkmaktadır. Veriye dayalı suistimallerin ve gizlilik ihlallerinin en aza indirilmesi için kişisel verilerin korunmasına yönelik hukuki düzenlemeler bulunsa da bu konuda asıl sorumluluk dijital müşterilere düşmektedir. 
Çalışmada ilk olarak reklamcılık sektörünün dijital medyadaki gelişim süreci ele alınarak, yeni reklam türleri tanıtımıştır. Bu kapsamda sektörde son dönemdeki en önemli yenilik olarak kabul edilen programatik reklamcılık konusuna yer verilmiştir. Daha sonra dijital tüketici kavramından bahisle reklamcılık alanındaki etik sorunlar tartışılmıştır.

Dijital medya reklamcılığı ve etik sorunlarla ilgili Türkçe yazında bir çalışmaya rastlanılamamış olup, uluslararası yazında yer alan Ingilizce araştırmalar taranarak bir derleme yapılmaya çalışılmıştır. Bilindiği üzere derleme çalışmalarında amaç başka araştırmacıların yaklaşımları ve fikirlerinin özetlenmesi ve bir sentez oluşturulmasıdır (Herdman, 2006).

Dijital medyanın doğuşu ile birlikte programatik reklamcılık kavramının ortaya çıkışı ve bunun getirdiği etik sorunlar oldukça yeni konulardır. Yenilikçi teknolojilerin reklamcılık sektörüne getirdiği karmaşık süreçler ile günlük hayatımızda karşımıza çıkan etik sorunlar, uluslararası yazından derlenen araştırmalar kapsamında ele alınmıştır. Dolayısıyla yapılan taramalarda özellikle veri gizliliği ihlalleri, kişisel verilerin kötüye kullanımı, tüketiciyi aldatıcı reklamlar ve pazarlama yöntemleri vb. konularla ilgili son beş yılda yapılan çalışmalardan bir sentez oluşturulmaya çalışılarak dijital medya reklamcılığı ile ortaya çıkan etik sorunlar örneklerle ele alınmıştır.

\section{Dijital Medyada Reklamcılık}

Geleneksel reklam verme sürecinde müşteriler, belirli bir format veya ortam içindeki belirli bir yerleşimin belirli bir miktarı için ödeme yapmaktadır. Miktar genellikle reklamın gösterileceği sürenin uzunluğuna ve yerleşimin söz konusu araçla alaka düzeyine, ölçeğine veya ölçeğe göre yerleştirilmesine bağlıdır (Gonzalvez ve Mochon, 2016).

Klasik medya reklamcılığında süreç:

- Reklamcı / medya ajansının reklam ağları / yayıncıları ile tek tek buluşmasıyla başlar,

- Sabit bir tıklama / gösterim ücreti için üzerinde anlaşmaya varılan tıklama / gösterim miktarıyla devam eder,

- Illgili yayının performansının ölçülmeye çalışıldığı manuel raporlama adımı ile sona erer.

Bu sürecin sonunda, rapora bakan reklamverenin soracağı veya en azından sorması gereken bazı basit sorular vardır. Örneğin, bu reklamlar ne tür bir hedef 
kitleye gösterildi? Reklamı gören veya tıklayan kullanıcılar sonraki kampanyalarda yeniden hedeflenecek mi? Yapılan gösterimlerin kaç tanesi gerçekte kullanıcı tarafindan görüldü? Ancak eski reklam araçları bu soruları cevaplamakta zorlanıyordu. Teknolojik olanakların artmasıyla yeni medya, insanların günlük yaşam pratikleri hâline geldi ve sosyal hayatı her yönüyle çevreledi. Bu kanallar, tüketici toplumu için işlevsel bir rol üstlenen reklamcılık sektörünü de büyük ölçüde etkilemiştir. Kurumlar, ürün ve hizmetlerini tanıtmak için geleneksel ortamların yanı sıra yeni medyada tanıtım faaliyetlerine yönelirken, insanlar bu kanallara aktif olarak katılarak tüketim faaliyetlerini yoğun bir şekilde yürütmeye başladı.

Yazılı, işitsel ve görsel medya araçlarının yer aldığı geleneksel medyada, kullanıcıların teknolojik özellikleri ve organizasyon yapısı nedeniyle sınırlı içerik sunulurken yeni medyada ses, grafik, resim ve makaleler üzerinde linkler yerleştirerek çeşitli içerikler sunabilmektedir. Yeni medyanın avantajı güncel bilgileri veya haberleri kullanıcılara hızlı bir şekilde sunabilmesidir (Carlson, 2005).

Çoğu zaman yaratıcı bir sektör olarak bilinse de reklamcılık endüstrisi uzun zamandır nicelleştirme, geri bildirim, analiz, doğrulama sistemleri ve reklamları hedefleme ve oluşturmaya yönelik makine benzeri yaklaşımlarla ilgilenmiştir. 1800 'lerin sonlarında endüstriyel üretim yöntemlerinin, dağıtımının ve yönetiminin yükselişine paralel olarak özel reklam ajanslarının yükselişi buna örnek olarak verilebilir. Bilimin deneyciliğinden ipuçları alan bu yaklaşım, açık bir şekilde neden ve sonuç, öngörülebilirlik, kontrol, veri ve reklam üretim sürecine kesinlik katma ihtiyacını vurgulamaktadır. Eskinin reklam devleri, yöntemlerine makineciliği dahil etseler de dinamik reklam deneyimleri oluşturmak için reklam içeriğinin alınmasıyla ilgili verilerin oluşturulması, hedeflenmesi, sunulması ve toplanması otomasyonunu tahmin edemezlerdi (McStay, 2017).

Kullanıcıların çok fazla zaman geçirdiği dijital medya kanalları, işletmeler için potansiyel müşterilerle bir iletişim ortamı olarak kabul edilmektedir. Düşük maliyeti, etkileşim özelliği ve veriye dayalı pazarlama özelliklerini kullanarak doğru hedef kitleye ulaşmanın avantajları nedeniyle dijital medya reklamları firmalar tarafindan daha fazla tercih edilmektedir. Günümüzde artan rekabetle birlikte markalar, tüketicilerin dikkatini çekmek ve onlarla iletişim kurmak için dijital medya reklamlarını tercih ederek geniş kitlelere çok hızlı şekilde ulaşabilmektedir. Böylece firmalar dijital medya reklamları ile ürünlerini potansiyel hedef kitlelerine tanıtabilir ve tüketicilerde satın alma isteği yaratabilirler.

Yeni medya ve tüketici ilişkilerinde markalar yeni medya ile geniş kitlelere ulaşabilmekte ve çift yönlü iletişim rahatlıkla sağlanabilmektedir. Bu durum, tüke- 
ticilerin sorunlarının daha kolay ve hızlı bir şekilde çözülmesine yardımcı olmaktadır. Bu bağlamda, yeni medya reklamcılığının geleneksel yöntemlere göre bazı avantajları vardır. Hedef kitle karşılıklı iletişimi mümkün kılan etkileşim imkânı sağlamaktadır. Yine geleneksel yöntemlere göre reklam içeriğinin reklamveren tarafindan hazırlanması ve yayıncı tarafindan yayınlanması hem zaman hem de maliyet açısından çok daha düşüktür. Dijital medya araçları reklamı revize etme firsat sağlar, örneğin yayınlanan bir gazetede kreatif güncelleme süreci kampanya devam etse bile artık bitmiştir ancak çevrim içi ortamlarda anında güncelleme her zaman mevcuttur (IAB, 2021).

Yeni medyanın yükselişi yeni iş modelleri için geniş firsatlar yaratmaktadır. Bugün tüketiciler Facebook ve MySpace'de eBay'deki perakendecilerden, YouTube'daki medya yapımcıları ve yöneticilerinden, Wikipedia'daki yazarlardan ve Amazon ve Tripadvisor'daki eleştirmenlerden daha fazlasını yapabilmektedir. Dolayısıyla dijital medya, kullanıcıların kendi tekliflerini geliştirmelerine ve dağıtmalarına da olanak sağlamaktadır. (Hennig-Thurau, v.d., 2010). Son on yılın dijital yenilikleri, izleyicinin zahmetsizce birbirleriyle iletişim kurmasını sağlamıştır (Deighton ve Kornfeld, 2009).

Günümüzde tüketiciler internette giderek daha fazla zaman geçirmektedir. İş yerinde, evde ve mobil uygulamalarda insanlarla, kuruluşlarla ve markalarla bağlant kurmak için sürekli firsatları vardır. Sosyal medya platformları, tüketicilerin öğrendikleri, bilgi paylaştıkları ve düşündükleri, satın aldıkları ve değerlendirdikleri markalarla etkileşime girdikleri dijital iletişim kanalları olarak ortaya çıkmaktadır. Sosyal medyayı kullanarak tüketiciyle sürekli ilgilenen şirketler, böyle bir ilişkinin marka gücünü ve dayanıklılığını güçlendirmek için kullanılabileceğini ve şirketlerin dijital medya yatırımlarından olumlu getiri elde edebileceğini kanıtlamıştır (Hudson, vd., 2016).

Dijital medya reklamları sadece bir ürün veya hizmetin satış veya tanıtımı için bir mecra değil, aynı zamanda marka imajına ve itibarına katkı sağlayan kurumsal reklam çalışmalarının yürütüldüğü bir platformdur. Ürün, hizmet ve kurumsal imajı destekleyen iki tür reklamı birlikte kullanabilme yeteneği, geleneksel reklamlara göre yeni medya reklamlarının en önemli avantajlarından biri olarak değerlendirilebilir. Örneğin hedef kitle tarafindan bir ürün veya hizmetin tanıtıldığı banner reklamlara tıklamak, doğrudan kurumun sanal mağazası olarak değerlendirilebilecek kurumsal web sitelerine yönlendirir. Bu nedenle hem kurumsal farkındalığı artıran hem de ürünleri tek bir reklamla tanıtarak satış faaliyetlerine katkı sağlayan iki farklı hizmeti bir arada sunmaktadır. 
Internette bilgi bombardımanına tutulan dijital tüketiciye doğru mesajı sunmak, pazarlamanın ana konusu hâline gelmiş durumdadır. Yeni medya araçları, markalar için proaktif çağın kapılarını açmış, tüketimin artth̆̆ bu dijital dünyada yerini almak isteyen şirketler için marka imajı oluşturmak her zamankinden daha zor hâle gelmiştir.

\section{Dijital Medyada Reklam Türleri}

Dijital medyadaki reklam türleri farklı kaynaklarda farklı şekillerde sınıflandırılabilmektedir. Geleneksel medya araçlarından dijital medyaya geçişle birlikte tüketicilerin kullandıkları medya ortamları (cep telefonu, tablet, laptop vd.) da çeşitlenmiş ve durum reklam sektörünü de farklı türler üretmeye zorlamıştır. Bu kapsamda, günümüzde dijital medya araçlarında en fazla kullanılan dokuz reklam türü aşağıda açıklanmaya çalışılacaktır.

\subsection{Görüntülü Reklamlar}

Görüntülü (display) reklamcılık, işletmelerin mesajlarıyla belirli web sitelerindeki belirli insan gruplarına ulaşmalarına olanak tanır (Google Digital Garage, 2021). Diğer bir deyişle, web sayfasında görünen reklamlar görüntülü reklamlardır. Bu reklamlar sayfanın üstünde, altında, solunda veya sağında bir banner şeklinde olabileceği gibi sayfanın içeriğinde de bulunabilir.

Görüntülü reklamlar arasında farklılık gösteren diğer bir reklam biçimi de zengin medya reklamlarıdır. Zengin medya reklamları, afiş ve açılır pencerelerden farklıdır; video yüksek sesli veya çoğunlukla etkileşimlidir. Flash, Java, Javascript gibi teknolojilerden birini veya birkaçını kullanırken dinamik HTML kodları da barındırılabilir.

\subsection{Mobil Reklamlar}

Uygun fiyatlı akıllı telefonların (Android, iOS ve Windows telefonlar) yaygınlaşmaSı, dijital cihazlar dünyasına bir dönüşüm getirmiştir. Bu akıllı telefonlarda çalışan uygulamalar genellikle mobil uygulamalar olarak adlandırılır. Mobil uygulamalar, uygulama geliştiricilerin mobil cihazların işlevlerini geliştirmelerine olanak tanır. SMS reklamı, mobil tarayıcı görüntülü reklamı ve mobil uygulamalardaki reklam gibi çeşitli cep telefonu reklamı türleri mevcuttur. Kullanıcılar mobil uygulamalarla mobil cihazlardaki diğer her şeyden daha fazla zaman geçirme eğiliminde olduklarından, mobil uygulamalardaki reklam, mobil reklamın en belirgin biçimi hâline gelmiştir. (Mukherjee, v.d., 2015). 


\subsection{Video Reklamlar}

1996 yılında ABD'de kurulan ve çevrim içi reklamcılık sektörünün otoritesi olarak kabul edilen Interactive Advertising Bureau (IAB), sektörün endüstri standartlarını geliştiren, araştırma yapan ve yasal destek sağlayan bir reklamcılık işletmesidir. IAB'nin "Video Reklam Şartları Listesi"ne göre 11 farklı video reklam biçimi vardır $(I A B, 2021)$ :

- $360^{\circ}$ Video Reklamcılığı: Videonun her yönünün çok yönlü bir kamera veya birden fazla kamerayla aynı anda kaydedildiği bir video türüdür.

- Reklam Bölmesi (Ad Pod): Televizyonda olduğu gibi video sırasında videonun başlangıcını, ortasını veya sonunu gösteren reklam dizilerinden oluşan bir biçimdir.

- Eğlence Reklam (Advertainment): Markanın mesajının hikâye olarak anlatıldığı formattır. Genellikle bir dakikadan uzundur.

- Otomatik Oynatılan Video Reklam: İzleyicinin etkileşimi olmadan başlayan reklamdır.

- Dinamik Reklam: Bu formatta hazırlanmış birden çok video, reklam mesajı ve harekete geçirici mesaj (ttklama) bölmesi, programatik bir yöntemle çeşitli kombinasyonlarda kullanıcılara ulaşır.

- Yayın İçi Video: Tüketilen içerik akışını kesintiye uğratarak gösterilen reklam türüdür.

- Etkileşimli Video: Video üzerinde bulunan çeşitli butonlar ve benzeri araçlar yardımıyla kullanıcı etkileşimine dayalı bir reklam formatıdır.

- Kısa ve Uzun Biçimli Video: Reklamın 10 dakikadan uzun veya daha kısa olan bir videoya eklenmesine göre tanımlanan biçimdir.

- Doğal Video: Kullanılan site veya uygulamanın bir parçası gibi görünen bir reklam videosudur.

- Akışı Olmayan Video: Ziyaret edilen sayfanın herhangi bir yerinde içerik dışı formda bulunan video reklamdır. Dört farklı çeşidi vardır: banner içi, yazı içi, devam eden ve geçiş reklamı.

- Dikey Video: Akıllı telefon formatına göre hazırlanarak tüm telefon ekranını kaplayan reklam türüdür.

\subsection{Sosyal Medya Reklamları}

Sosyal medya, insanların sanal ortamda topluluklar oluşturmasını sağlayan ortak bir araçtır. İnsanların diğer insanları veya grupları etkilemek amacıyla konuyla il- 
gili bir şeyler yayınlamak için kullandıkları yüksek düzeyde erişilebilir ve yaygın iletişim teknikleri veya teknolojileri olarak tanımlanır. Başka bir deyişle, bilginin insanları içerik okuyucularından içerik yayıncısına dönüştürecek şekilde demokratikleşmesi olarak ifade edilebilir.

Bir markayla sosyal medya aracılığıyla etkileşim kurmak, kişiler arası bir sosyal etkileşim işlevi görebilir ve duygusal bir bağlılık ve yakınlık duygusu geliştirebilir. İki yönlü iletişim ve etkileşim, sosyal medyayı, müşteriler ve şirketler arasında ürün ve hizmet teklifleri sunarak çekici markalaşma potansiyeli sunar (Hudson, vd., 2016).

\footnotetext{
"Pazarlamacılar, sosyal medya aracılığıyla mevcut ve potansiyel müşterilerle iki yönlü iletişim kurarak etkileşime girebilir ve doğrudan tüketici iç görülerini daha hızlı bir şekilde elde edebilir. Pazarlamacılar ayrıca sosyal medya ağlarının, marka referanslarının ve bilgi paylaşımının değerini de fark ettiler. Facebook'a göre, ortalama bir kullanıının sosyal ağda 130 arkadaşı bulunmaktadır ve insanlar bir arkadaşından bir ürün veya hizmet duyduklarında, diğer yollardan öğrendiklerinden yüzde 15 daha yüksek oranda o ürünü satın alma eğilimine sahipler" (Baker, 2009).
}

Geleneksel pazarlama, kuruluşlar ve tüketiciler arasındaki etkileşimin ilk aşamasında marka bilinci ve ilgi yaratmada önemli bir rol oynadı. Etkileşim ilerledikçe ve tüketiciler kuruluşlarla daha yakın ilişkiler talep etmeye başladıkça sosyal pazarlamanın önemi artt. Sosyal pazarlamanın en önemli işlevi, kurumlar ve tüketiciler arasındaki çevrim içi ve çevrim dışı etkileşimi birleştiren, marka geliştirmede stil ve özü harmanlayan ve nihayetinde tüketici katılımını artırarak makineden makineye bağlantıyı insan-insan dokunuşuyla tamamlayan bir pazarlama yaklaşımı oluşturmasıdır (Kotler, vd., 2017, s. 84-85).

Dijital medyanın ortaya çıkmasıyla birlikte geleneksel medya kanalları ve özellikle yüksek bütçeli televizyon reklamları artık müşterilerin satın almalarını etkileyen en önemli faktör olmaktan çıkmaktadır. Son zamanlarda yapılan televizyon reklamlarında bile ilgili markanın sosyal medya kanallarına yönlendirildiği görülmektedir. Markaların sosyal medya aracılığıyla gerçekleştirdiği en yaygın pazarlama iletişimi biçimi ağızdan ağza pazarlamadır. Bunu başarmak için farklı içerikler oluşturmak, hedef kitlenin ilgisini çekmek ve güvenini kazanmak nihai hedefler arasındadır. Sosyal medya araçları, tüketicilerin davranışları üzerinde önemli bir etkiye sahip olduğu ve yol gösterici bir doğası olduğu için kuruluşlar için değerli bir platformdur. 


\subsection{Arama Motoru Reklamları}

Arama motoru reklamı, yalnızca kullanıcılar bir arama motorunda anahtar kelime aradıklarında görünür. Bu, arama motoru pazarlamacılığı (SEM) olarak bilinir. Arama reklamları metin tabanlı olup belirli bir konuyla ilgilenen kişilerin önüne içerik koymanın ideal bir yoludur. Bir kişi bir arama motorundan uzaklaştığında, arama reklamları artık onu hedefleyemez. Burası görüntülü reklamların devreye girdiği yerdir. Bunlar, ücretli reklam alanı bulunan herhangi bir web sitesinde görünebilir. Görüntülü reklamlar grafik, ses ve hatta video içerebildiği için çok daha ilgi çekici olabilirler (Google Digital Garage, 2021).

Arama motoru reklamcılığını kullanan reklamverenler, reklamlarını aktif olarak belirli anahtar kelimeleri arayan kullanıcılara gösterir ve kullanıcılar reklamı her tıkladığında bir ücret öderler. Bu tür reklamcılık özellikle etkilidir çünkü arama yapan kişiler, arama sorgularıyla niyetleri hakkında çok şey ortaya koyma eğilimindedir. Dinamik bir yapıya sahip olan arama motoru sonuçları, sosyal medya, güncel haberler, algoritmadaki değişiklikler ve diğer bazı faktörler nedeniyle her an değişebilir. Sanal ortamda olumlu bir algı oluşturmak süreklilik arz eden bir süreçtir ve tüm markalar bu sürece dahil olma ihtiyacını hissetmektedir. Dolayısıyla arama motoru reklamcılığı günümüzde en fazla kullanılan dijital reklam türlerinden birisidir.

\subsection{Konum Bazlı Reklamlar}

Mobil telefonlarının kullanımının artmasıyla birlikte ortaya çıkan konum bazlı reklamcılık, kullanıcının konumunu GPS ile anlık olarak takip ederek bulunduğu bölgeye özel reklamların karşısına çıkartılmasına dayanmaktadır. Birinin nerede olduğunu ve ne yaptığını anlık olarak gösteren veriler, konum bazlı etiketlemenin önemini artırmakta, bu durum reklamverenlerin iştahını kabartmaktadır.

Her geçen gün daha fazla yerel işletme, konum bazlı verilere dayalı mobil teknolojiden faydalanmaya başlamış durumdadır. 1.483 tüketici arasında yapılan bir ankete göre, tüketicilerin $588^{\prime} i$, her gün mobil cihazları üzerinden en az bir yerel işletme reklamı ile karşılaştıklarını belirtmişlerdir (Digitaltalks, 2016). Dolayısıyla konum verileri artık girişimciler için oldukça güçlü bir pazarlama aracı hâline gelmiştir.

\subsection{Doğal Reklamlar}

Doğal reklamlar görüntülü reklamlara benzer, ancak yerleşim ve kitle hedefleme söz konusu olduğunda daha stratejik ve niyet odaklıdır. Akışa entegre edilmiş ve kamufle edilmiş sponsorlu girişlerdir. Doğal reklamcılık, hedef kitlenin çevrimiçi 
alışkanlıklarına ve geçmişine dayanır ve kendileriyle alakalı olabilecek reklamları gösterir.

Doğal reklamcılık, kullanıcılar için en az rahatsız edici olan reklam türüdür çünkü gördükleri büyük olasılıkla kendileriyle ilgilidir. Çoğu zaman, kullanıcılar doğal reklamları ilgi alanları ile çok alakalı oldukları için yararlı bulabilmektedir. Örneğin bir alışveriş sitesinde kullanıcılar bir ürün aradığında, ilk birkaç seçenek büyük olasılıkla kullanıcının isteyebileceği ürünle alakalı sponsorlu ürünler olacaktır. Doğal reklamlar, web sitesi veya platform tarafindan sponsorlu olarak etiketlenecektir.

\subsection{E-posta Reklamları}

Reklamverenin ilgili kullanıcılara elektronik posta yoluyla mesajlarını iletmesidir. Firmalar; haber, e-bülten, güncellemeler, yeni ürün duyurusu, indirim, promosyon gibi birçok bilgiyi doğrudan kullanıcılarına ileterek reklam faaliyeti yürütebilmektedir. E-posta reklamları diğer reklam türlerinden farklı olarak daha fazla kişiye daha düşük maliyetlerle ulaşmayı başarabilmektedir. Ayrıca ölçümlenebilir olması internet reklamcılığı için etkili yöntemlerden biri olduğunu göstermektedir.

\subsection{Programatik Reklamlar}

Programatik reklamcılık veriye odaklıdır ve tüketici davranışlarını analiz eder. Davranışsal reklamcılıkta segmentasyon tipik olarak yaş, cinsiyet, gelir, coğrafya, eğitim, dünya görüşü ve ilgi alanları gibi beş ila on özelliğe dayanmaktadır (McStay, 2017).

Programatik ticaret, büyük veri teknolojilerinin bir biçimidir ve bu veriler kullanıcıların dijital profilleri ve çevrim içi davranışları ile ilgili verilerdir. Bu nedenle programatik reklamcılık, kişisel bilgileri toplama, işleme, yönetme ve etkin bir şekilde kullanma kapasitesinin "kişisel bilgi ekonomisi" olarak adlandırılan kavramın bir parçasıdır (Acquisti, 2009).

Programatik reklamcılığı diğer reklam türlerinden ayırt eden en önemli özellikler şu şekilde sıralanabilir (Busch, 2016):

- Seçicilik: Her bir reklam görüntüleme firsatının kendi genel parametreleri, belirtilen alıcıları ve belirli reklam ortamları dikkate alınarak eksiksiz bir şekilde değerlendirilmesidir. Seçicilik, her bir reklam görüntüleme firsatının seçimini, değerlendirmesini, fiyatlandırmasını ve tasarımını bilimsel yöntemlerle benzeri görülmemiş bir şekilde detaylandırarak reklamverenlerin bütçeyi en uygun şekilde kullanmasını sağlar. 
- Gerçek zamanlı süreç: Reklamın tasarımı sırasında en güncel verileri kullanarak belirli bir reklamvereni veya belirli bir reklam firsatını gösterme kararıdır.

- Gerçek zamanlı bilgi: Mevcut firsatın belirli özellikleri ve en güncel ampirik veriler temelinde görüntüleme firsatının değerlendirilmesidir.

- Gerçek zamanlı tasarım: Reklamverenler, ilgili reklam firsatını elde ettikleri anda en uygun reklamı dinamik ve veriye dayalı bir şekilde sunarlar.

- Otomasyon: Otomatik alan rezervasyonu ve reklam sunumu sürecidir. Her bir reklam görüntüleme firsatını, reklam kampanyası döneminde insanların yapamayacağı kadar yüksek bir ayrıntıyla geniş bir karar alma sürecine tabi tutma otomasyonla sağlanır.

Programatik reklamcılık, her yeni medya reklamı görüntüleme firsatını değerlendirme ve çoğunlukla müzayede yoluyla anlık verilere göre teklif verme ve alan kazanılması durumunda ilgili reklamın milisaniyeler içinde (saniyenin binde biri) çok detaylı bir şekilde otomatik olarak tasarlanması sürecini içeren reklamcılıktır.

Bir reklam değişiminin işlevi, reklamverenlerin veya onlar adına hareket eden bir aracı ajansın, bir reklamı gerçek zamanlı olarak sunmak için teklif vermesine izin vermektir. Bu "gerçek zamanlı" reklam için süreç şu şekilde işler: Kullanıcı çevrim içi bir cihaz kullanmaktadır, cihaz bir reklam sunucusundan bir reklam ister, istek bir reklam borsasına yönlendirilir, bir reklam sunma firsatı gerçek zamanlı olarak teklif edilir, kazanan reklamı sunar ve kullanıcı reklamı görür.

Bir reklamverenin teklifinin başarısı, kullanıcının türü ve ilgi alanlarıyla ilgili verilere göre belirlenir. Reklam borsasının rolü, açık artırmaya ev sahipliği yapmak ve belirli bir reklam için doğru kullanıcıyı, belirli bir ortamda, reklamverenin ödemeye hazır olduğu bir fiyattan belirlemektir. Reklam stoku; görüntülü, zengin medya, video, mobil, tablet ve sosyal medya envanterini içerir. Aynı müşteriyi aynı anda arayan birden fazla reklamveren olduğundan, gerçek zamanlı satın alma borsaları, potansiyel müşteriye kimin en uygun olduğuna karar vermek için gerçek zamanlı açık artırmalar düzenler. Açık artırmanın galibi ve reklam alanının fiyat, bağlama (sitenin ürün / hizmet / organizasyon türüyle alaka düzeyi) ve kitleye (izleyicinin reklamveren için ne kadar iyi bir eşleşme olduğu) göre belirlenir (McStay, 2017). 
Geleneksel reklamcılıkta farklı özelliklere, alışkanlıklara, tüketici davranışlarına sahip geniş bir tüketici segmentine tek bir genel reklam sunulmakta iken programatik reklamcılıkla kişiye özel ve bire bir pazarlama ölçeğinde ayrıntılı kontrolle kampanyalar yürütülebilmektedir. Geçmişte tamamlanması haftalar süren reklam satın alma süreci, gelişmiş otomasyon teknolojileri ve hassas tüketici veri profilleri sayesinde milisaniyeler içerisinde gerçekleşmektedir. Sonuç olarak pazarlamacılar reklam harcamalarından daha güçlü getiri elde etmektedir.

“Pazarlamacıların \% 87'si, geleneksel medya satın almaya kıyasla programatik reklamlardan daha fazla gelir elde etmekte ve bu tür bir verimlilik artışı, pazarlamacıların harcamalarının \% 50'sinden fazlasını programatik için ayırmaya teşvik etmektedir." (AdRoll, 2016; Akt. Watts, 2016).

Veri toplama araçlarının gelişmesi, pazarlamacılar açısından daha fazla verimlilik, gelişmiş hedefleme ve optimize edilmiş kampanyalar düzenleme firsatları sunmaktadır. Bu firsatları hayata geçirmede programatik reklamlar etkinlik ve etkililik açısından birkaç adım öne çıkmaktadır.

\section{Programatik Reklamcılık ve Veri Gizliliği}

Programatik reklamcılık, potansiyel tüketicilere gerçek zamanlı olarak son derece kişiselleştirilmiş reklamlar sunmak için web tabanlı teknolojileri kullanan milyarlarca dolarlık bir iş modelidir. (White ve Samuel, 2019). Programatik reklamcılık sistemi; veri yönetim platformlarından (DMP) ve çerez (cookie) olarak depolanan verilerden beslenir. Bu veriler, tüketicilerin tarama alışkanlıklarını, satın alma geçmişlerini ve kişisel tercihlerini depolayan profillerden elde edilir. GPS konumu, güncel aktiviteler ve hava koşulları gibi diğer veriler de kullanılabilir (Gertz ve McGlashan, 2016). Arz Tarafi Platformları (SSP) ise mevcut reklam alanlarının envanterini yönetir. Talep Tarafi Platformları (DSP), müşteri ile katılımcı kuruluşların reklam materyalleri arasındaki uyumu değerlendirmek için veri yönetimi platformu (DMP) profillerini kullanır, ardından bu web alanının değerini hesaplar ve katılımcı kuruluşlar adına açık artırma tarzı teklif verme işlemini gerçekleştirir. Programatik ticaret sürecinde veri yönetimi platformları (DMP'ler), tüm kanallarda ve cihazlarda bir tüketici kitlesini akıllıca tanımlamak, hedeflemek ve izlemek için kullanılabilecek tek ve tutarlı bir metrik kümesi üretmeye yardımcı olur. DMP'ler, reklamları doğru tüketiciye, doğru zamanda ve doğru bağlamda tam olarak sunmak için talep tarafi platformlarıyla (DSP'ler) birlikte çalışır (Watts, 2016).

Reklam alım satım süreci insanlar yerine makineler arasında gerçeklemektedir. Programatik reklamcılığı bu kadar özel kılan en önemli unsur olan kullanıcı verileri ile olan ilişkisidir. Programlı altyapı, hem reklamverenlere, yayıncılara hem de 
üçüncü taraf veri şirketlerine kullanıcı verilerinden yararlanma şansı vermektedir. Böylelikle reklamveren, özellikleri detaylı bir şekilde belirlenen hedef kitleye reklam gösterebilmektedir. Tüketici veriler üç aşamalı bir işlevi yerine getirmektedir; reklamları belirlemek, hedeflemek ve yayınlamak. ilk durumda, veriler profillere entegre edilir, böylece belirli kullanıcıların mevcut gösterimlerle eşleştirilmesine izin verilir. Hedefleme verileri, belirli bir kullanıcının belirli bir gösterim için değerini kampanya parametrelerine göre belirlemede çok önemlidir (IAB, 2021).

E-sağlık veya belirli öneri sistemleri (ör. Netflix veya Amazon) gibi diğer veriye dayalı hizmetler birinci veya ikinci veri tarafi yönetimine bağlı olsa da üçüncü taraf veri oynatıcılarının önemi programatik ekosisteme ve dolayısıyla reklamcılığa özgüdür. Üçüncü taraf veri oyuncuları, veri izlenebilirliğini güvence altnna alma sorunları nedeniyle genellikle güvenlik açıkları ve ilgili gizlilik sorunlarına yanıt vermemeleri nedeniyle sorgulanmaktadır (Ponemon Institute, 2016). Üçüncü taraf veri sağlayıcılarının yaygınlığı nedeniyle, programatik ticaret süreci çoğunlukla kullanıcılar tarafindan fark edilmeden kalır. Bu durum, izin talebi ve bilgili karar verme gibi dijital gizlilik endişelerini ele almada yetersizliklere yol açabilir (Martinez-Martinez, vd., 2017). Mevcut bilgi eksikliği ve artan kullanıcı duyarlılığının birleşimi, reklam endüstrisinin dönüşümü için ek itibar zorlukları içermektedir (Watts, 2016). Bunun yanında, programatik reklamcılık mevcut çerez bazlı hedeflemeler nedeniyle belli sınırlamalara sahiptir. Bu reklamların birçoğu reklamverenler tarafindan toplanması bir hayli zor olan ve çeşitli veri sağlayıcılar tarafindan toplanan üçüncü parti verilere dayanmaktadır.

İşlenen verilerin eksiksizliği, izleyicilerin göz atma ve bağlamsal verileri edinmenin kullanılabilirliğine ve maliyetine bağlıdır. Bu nedenle, daha eksiksiz veri ve genel olarak daha fazla veri elde edebilen herhangi bir platformun belirgin bir rekabet avantajına sahip olacağı sonucu çıkar. Bununla birlikte, daha eksiksiz veri elde etme yeteneği yalnızca maliyetle değil, aynı zamanda çağdaş yasalar ve izleyicilerin gizlilik ihlali algılarıyla da sınırlıdır. Bu, programatik reklam sistemindeki temel bir çelişkiyi vurgulamaktadır: izleyici-reklam eşleştirmesinin etkinliğini artırmak için izleyicilerin dijital mahremiyetlerine ilişkin endişelerini artıran miktarda veriye intiyaç vardır (White ve Samuel, 2019). Ayrıca programatik ticaret ekosisteminde verilerin kullanılabilirliği, veri kalitesiyle ters orantılıdır. Piyasada daha büyük bir varlığa sahip olan üçüncü taraf verileri - tam olarak daha az kaliteli ve yasal ve etik olarak daha hassas olan verilerdir (Ponemon Institute, 2016).

Kişisel verilerin gerçek ve algılanan etik kullanımı ve işlenmesi, platform geliştiricilerinin ve katılımcı kuruluşların dikkatlice düşünmesi gereken acil bir sorundur (White ve Samuel, 2019). Kişisel verilerin bu kadar yoğun kullanımı, mahremiyet 
ve güvenlikle ilgili endişeleri de artırmaktadır. Gizlilik, kullanıcıların dijital yaşamla ilgili endişelerinin başında geliyor gibi görünse de çevrim içi davranış bu endişeleri yansıtma eğiliminde değildir (Rainie ve Duggan, 2016). Bu sözde "gizlilik paradoksu" (Watts, 2016), genellikle risk algısı veya algılanan faydalar gibi davranışsal değişkenlerle ilişkilidir. Bu noktada yine tüketicilerin veri paylaşımı ve veri gizliliği konusundaki farkındalıkları ve buna yönelik hassasiyetleri ön plana çıkmaktadır.

Bilişim teknolojilerinde yaşanan gelişmeler sonucunda veri işlemenin kolaylaşması neticesinde, işlenen verinin çeşitliliğinin ve miktarının artmasına bağlı olarak kişisel veri niteliğindeki bilgiler uzun süredir toplanmaktadır. Bu durum, bazen kanunlardan kaynaklanmakta bazen kişilerin rızasına veya bir sözleşmeye dayanmakta bazen de yapılan işlemin niteliğine bağlı olarak ortaya çıkmaktadır. Mal ve hizmetlerin ekonominin gereklerine uygun biçimde geliştirilmesi, dağıımı ve pazarlanması için kişisel verilerin toplanması kaçınılmaz olmakla birlikte, verinin ekonomik bir değer niteliği kazanması neticesinde de kötüye kullanımı üzerindeki riskler artmıştır (KVKK, 2019).

Programatik reklamcılık gibi yeni teknolojiler önemli etik ve itibara ilişkin sonuçları olan karmaşık süreçlere yol açmaktadır. Bu nedenle, dijital medyada hızla gelişen reklamcılık sektöründe yetenekleri uyarlama ihtiyacı ortaya çıkmaktadır. Yapılan çalışmalarda profesyonellerin görüşleri ile kullanıcıların algıları arasında büyük çelişkiler belirlenmiş, bu araçların sorumlu kullanımı ve bunların sonuçlarını belirleme becerisinde çeşitli profesyonel ve işlevsel zorluklar olduğu görülmüştür (Martinez-Martinez, v.d., 2017). Bununla beraber tüketicilerin veri gizliliğine ne kadar önem verdikleri, çok tartışılan bir sorudur. Veri gizliliğini çok fazla önemseyen ve verilerinin reklamlarda kötüye kullanılmasıyla ilgili endişelerini mevzuat düzenleyicilerine dile getiren güçlü bir gizlilik aktivisti grubu bulunmaktadır. Ancak kitlesel kamuoyuna gelince, medya endüstrisi görüşleri, verilerinin açık borsada reklam satın alma ve ticaretinde nasıl kullanıldığını gerçekten anlarlarsa tüketicilerin bu konuyu o kadar önemseyebileceklerini belirtmektedir (Davies, 2019). Dolayısıyla tüketicilerin veri gizliliği konusunda daha fazla bilinçlendirilmesine ihtiyaç bulunmaktadır.

\section{Dijital Tüketici Kavramı ve Etik Sorunlar}

Tüketici kavramı, geniş anlamda, ihtiyaçlarını karşılamak için piyasadan ürün veya hizmet satın alan kişi olarak tanımlanabilir. Bununla beraber ürün ve hizmetleri satın almak ve satmak için teknolojiyi kullanan kişiler dijital tüketiciler olarak bilinir.

Insanlar binlerce yıldır birbirleriyle iletişim ve etkileşim hâlindedir. Zaman geçtikçe gelişen iletişim kanalları ve internet insanları birer dijital tüketiciye dönüştürmüştür. Tüketici davranışları da dijital teknolojinin olanak sağlayan doğası ve bilgi- 
ye kolay erişim nedeniyle değişmekte, insanlar hakkında varsayımlar oluşturmak, dijital tüketiciler söz konusu olduğunda ideal bir yaklaşım olmaktan çıkmaktadır. Pazarlamacılar, dijital tüketicilerin davranış özelliklerini anlamak için kapsamlı araştırmalar yapmaktadır. Bu kapsamda ortaya çıkan dijital tüketici özellikleri şu şekilde özetlenebilir (Reach First, 2021):

- Dijital tüketiciler oldukça bilgilidir: Insanlar artk internetin gücünden tam olarak nasıl yararlanacaklarını öğrendiler. Insanlar modern iletişim teknolojisinin daha fazla farkına vardıkça onu daha verimli kullanmaktadırlar. Bu, pazarlamacıların iyi bilgilendirilmiş potansiyel müşteriler kazanmak için ellerinden gelenin en iyisini yapması gerektiği anlamına gelir.

- Alakalı ve hızı bilgi talep ederler: Aşırı bilgi ve çeşitli seçenekler, insanları saniyeler içinde doğru ve tehlikesiz çözümleri almaya alıştırmıştır. Örneğin, bir alışveriş web sitesi yanıt vermiyorsa veya yavaşsa, ziyaretçiler büyük olasılıkla geri dönecek ve bir sonraki seçeneğe geçecektir. Bir ziyaretçinin siteyi sevmesini sağlayan anlık memnuniyettir.

- Çok şey paylaşırlar: Çevrim içi tüketiciler, deneyimleri hakkında konuşabilecekleri, değerli bilgileri paylaşabilecekleri, öneriler isteyebilecekleri, incelemeler sunabilecekleri ve yorum bırakabilecekleri sınırsız firsatlara ve platformlara sahiptir.

Günümüzde pazarlama sektörünün en önemli değeri "kişisel veriler" ve bunların analizidir. Tüketicilerin yakından takip edebilmesi ve pazarlama faaliyetlerini tüketici beklentilerine göre şekillendirebilmesi veri ihtiyacını doğurmaktadır. Dolayısıyla veriler; sosyal veriler, e-posta, abonelikler, cihaz bilgileri, konum bilgisi, kredi kart bilgileri, çevrim içi işlem verileri dahil olmak üzere izleme araçları aracılığıyla kullanılabilen her türlü profil kaynağını içermektedir.

Yeni medya, şirketlere tüketicilere ulaşmaları, onlarla iletişim kurmaları, göz atma veya satın alma ile ilgili davranışlarını ölçmeleri için çok çeşitli yollar sunar. Bu seçenekler genellikle pazarlama için değerlidir ancak, bireysel pazarlama etkinlikleri oluşturmada müşteriler hakkındaki bilgileri kullanan firmalar için daha özel bir önem taşır. Dijital medyanın sunduğu firsatları kullanmak, tüketicilerin nelerden etkilendiklerinin ve bunların etki ve davranışlarını nasıl etkilediklerinin tam olarak anlaşılmasını gerektirir. (Hennig-Thurau, vd., 2010). Ancak firmaların bu çabaları doğrultusunda yaptıkları gizlilik ihlalleri günümüzde büyük bir tartışma konusudur.

Programatik reklamcılığın temelini oluşturan tüketicilerin çevrim içi ortamdaki davranışlarının izlenmesi, tüketici mahremiyetinin suistimalini arttırmaktadır 
(Watts, 2016). Günlük hayatımızda sıklıkla karşılaşth̆̆ımız üzere cep telefonu uygulamalarının hemen hepsi daha programı yükleme aşamasında kullanıcıdan pek çok erişim izni talep etmektedir. Bunlar konum bilgisi, telefondaki rehbere, arama kayıtlarına, fotoğraflara erişim gibi izinler olabilmekte, izin verilmediği takdirde bu programlar yüklenememektedir. Ancak gizlilik ihlaline çok açık olan bu tip kişisel verilerin nasıl analiz edildiği, nerede saklandığı, kimlerle paylaşıldığı konusunda firmalar tatmin edici bilgiler sunamamaktadır.

Bunların yanında Google'ın insan beyninin nasıl çalıştığını inceleyen teknolojisi nöral ağ ile her konum bazlı etikete bir kaynak bağlayabilmekte, böylelikle pazarlamayı daha güçlü ve kişiselleştirilmiş hâle getirebilmektedir. Google'ın nöral ağı bir fotoğrafin nerede çekildiğini belirleyebilmekte, böylelikle mobil kullanım ve mobil reklamcılığın peyzajı, yepyeni bir alana taşınmaktadır (Digitaltalks, 2016). Bu gibi veri analizine dayalı teknolojiler masum görünse de gelecekte bu verilerin farklı amaçlarla kullanılabilme ihtimali insanları endişelendirebilmektedir.

\begin{abstract}
"Algoritma doğruluğu" ve "veri etiği" reklamcılıkta en önemli unsurlardandır. Bu sistem için büyük ve canlı veri kümeleri mevcuttur. Ayrıca bu veri setlerinin edinilmesi ve işlenmesi engelleyici bir şekilde pahalı değildir. Üstelik bu kadar büyük miktarda bilginin elde edilmesi, faaliyetin uygulandığı ülkelerde yürürlükte olan mevzuat tarafindan yasaklanmamaktadır. Büyük miktarlarda son derece kişisel bilginin elde edilmesi, tüketicilerin bunun bir tür gizlilik ihlali olduğunu algılamasına neden olmaz. Dolayısıyla reklam platformları anlık olarak "mükemmel algoritmalar" geliştirmektedir (White ve Samuel, 2019).
\end{abstract}

Watts tarafindan yürütülen bir araştırma, veri gizliliği konusunda tüketiciler arasında bir paradoks olduğunu göstermektedir. Bazıları tarafindan mahremiyet paradoksu olarak adlandırılan bu paradoks, insanların kendi kişisel bilgilerini koruma konusunda tutarsız ve çelişkili dürtülere sahip olduğunu söylemektedir. Tüketicilerin veri toplamaya yönelik bu tutumları göz önüne alındığında, büyük verinin zarar verme gücüne sahip olduğu ortaya çıkmaktadır. Verimli ve kazançlı pazarlama firsatlarını besleyen büyük verinin arkasında, veri simsarlarının tehlikeleri vardır. Çevrim içi davranıştan tıbbi geçmişe, cinsel ve politik yönelim ve hatta psikiyatrik sorunlara kadar değişen tüketici verileri satın alınabilir. Bu tür kişisel veri toplama, pazarlamacıların doğru tüketiciyi doğru bağlamda daha kesin bir şekilde bulma becerisiyle sonuçlanan bir tüketici tehdididir. Dolayısıyla söz konusu paradoks, kişisel veri toplama ve kullanımında da daha fazla şeffaflığa ihtiyaç olduğunu göstermektedir (Watts, 2016).

Yeni medyanın tüketicilere kendilerini ifade etme ve tercihlerini çevrim içi olarak 
ifade etme firsatı sunması, pazarlama faaliyetlerini yeni araçlarla yürütmek, tüketicilerle iletişim kurmak ve onların fikirlerine hızlı bir şekilde ulaşmayı isteyen tüm şirketlere büyük fayda sağlamaktadır. Geleneksel medya araçlarıyla karşılaştırıldığında, yeni medya araçlarının pazarlama yaklaşımına getirdiği yenilikler sadece teknolojik özelliklerden değil, aynı zamanda tüketiciler ve şirketler arasında iletişim kurmak için sosyal bir bağlant kurma firsatı vermektedir.

Yeni medyanın pazarlamaya getirdiği ölçülebilirlik; interaktif pazarlama ve tüketici ilişkileri gibi alanlarda pek çok yenilik sağlamıştır. Artık markalar pazarlama iletişimi faaliyetlerini anlık olarak takip edebilmektedir. Satış sonrası oluşacak müşteri memnuniyeti, şikâyet, öneri ve diğer taleplerin sosyal ağlar üzerinden paylaşılması, firma itibarını online olarak kontrol etme imkânı sağlamaktadır. Ancak insanlar edindiği herhangi bir bilgiyi veya bir konuyla ilgili kişisel yorumlarını, üye oldukları bir blog, forum veya sosyal medyada paylaşarak düşüncelerini daha çok kişiye hızlı bir şekilde iletebilmektedir. Bu sayede dijital medyanın bir parçası olabilmekte ve paylaşılan içerik binlerce kişi tarafindan yakından takip edilebilmektedir. Bu durum bazı etik sorunları da beraberinde getirebilmektedir.

Dijital medya ürün ve hizmet deneyimlerinin ve görüşlerinin viral bir şekilde yayılması yoluyla farkındalık ve ilgiyi artırmak için büyük bir potansiyel sumaktadır (Baker, 2009). Marka iletişim uzmanları, tüketiciler arasında marka algısını iyileştirmek ve marka bilinirliğini artırarak tercih edilen bir marka hâline gelmek için sanal ortamda çeşitli çalışmalar yapmaktadır. Bunun bir parçası olarak, özellikle bir hizmet veya ürün hakkında olumsuz deneyimler paylaşan kişiler, sanal ortama yayılıp hizmet algısı açısından olumsuz bir durum oluşturabilmektedir. Diğer kullanıcıların da bu tür olumsuz yorumlar görmeleri muhtemeldir. Kullanıcıların paylaştığı yorumlar doğru ya da yanlış olsa bile bu tür olumsuz arama sonuçlarının sanal ortamda görüntülenmesi markanın piyasadaki algısını zedeleyebilmektedir. Olumsuz yorumların silinmesi veya sildirilmesi ise diğer bir etik sorundur. Yani tüketicinin olumsuz deneyimlerinin bir nevi sansürlenmesi "özgürlükçü" sanal platformlara olan güveni sarsabilmektedir.

Etik sorunlardan bir diğeri de sahte hesaplar (botlar) aracılığı ile web trafiği yaratmaktır. "Bot" olarak adlandırılan sahte hesaplar yaratılarak istenilen alanda web trafiği oluşturulmasıyla reklam pazarından pay alınması amaçlanan bu etik olmayan faaliyetler sonucunda yılda yaklaşık 6,3 milyar dolarlık bir sahte reklam pazarı oluştuğu tahmin edilmektedir (ANA, 2014). Bot trafiği, saldırıya uğramış günlük bilgisayarlardan gelmektedir. Amerikan Ulusal Reklamcılar Derneği (ANA) tarafindan yapılan araştırmaya göre (2014), gözlemlenen bot trafiğinin yüzde 67'den fazlası konut IP adreslerinden gelmektedir. 
Bot yönlendiricileri, reklam sahtekârlığından kâr elde etmek için ev bilgisayarlarını uzaktan kontrol eder. Botlar, gerçek kullanıcılar gibi görünmek, insan trafiğine karışmak ve daha fazla gelir elde etmek için tarayıcıları ele geçirir. Reklam botları, kullanıcı hedeflemeyi geçersiz kılar. Örneğin Gmail'de oturum açmış, Facebook'ta paylaşımda bulunan ve Amazon'da alışveriş yapan gerçek kişilerin bilgisayarlarını kullanarak siber suçlular gerçek kullanıcıların kimlik bilgilerine ulaşır. Botlar, reklam alanlarına gerçek insanlardan daha sık tıklamakta, fareyi hareket ettirerek imleci reklamların üzerine taşımaktadır. Botlar ayrıca, ürünleri alışveriş sepetlerine koyabilir, reklamverenlere ve yayıncılara demografik olarak daha çekici görünmek üzere geçmişler ve çerezler oluşturmak için birçok siteyi ziyaret edebilir. Dolayısıyla sahte hesap (bot) yaratarak olmayan bir web trafiği oluşturma faaliyetleri ile yeni bir reklam sahtekârlığı türü ortaya çıkmaktadır. Bu reklam sahtekârlığı, reklamların doğru zamanda, doğru yerde doğru kişilere doğru şekilde sunulmasını engelleyen kasıtlı bir faaliyettir.

Reklamlardaki etik dışı uygulamalar, toplumsal yapının olumsuz etkilenmesi ve tüketicilerin aldatılması nedeniyle günümüz toplumlarında daha fazla dikkate alınmaktadır. Dolayısıyla reklam; doğru, güvenilir, dürüst ve toplumun kültürel ve etik normlarına uygun olmalıdır. Tüketiciler etik ilkelere daha duyarlı hâle geldiklerinden, kuruluşlar reklamcılıkta etik konulara daha özen göstermeye teşvik edilmektedir. Aldatıc reklamlar, cinselliğin özendirilmesi, çocuklara yönelik reklamcılık ve reklamcılıkta ayrımcılık, reklam etiği literatüründeki diğer başlıca konulardır (Koç, vd., 2016).

\section{Değerlendirme ve Sonuç}

Internet, bir reklam aracı olarak geliştiricilere yaratıcılık için sonsuz firsatlar sunmaktadır. İnternet ekosisteminin büyümesi ve gelişmesi dijital reklamcılık sektörünün büyümesine ve gelişmesine yol açmıştır. Dijital medyanın reklamcılık için sunduğu imkânların bir sonucu olarak en güncel verileri gerçek zamanlı ve otomatik olarak çevrim içi kullanan programatik reklamcılık, yeni medya reklamcılığındaki en önemli gelişmelerden biridir.

Merkezi profil veri tabanları, birinci ve üçüncü taraf verilerine küresel erişim, minimum bilgi kaybı ve anlamsal istatistiksel eşleştirme, dijital reklamların başarısının arkasındaki itici güçtür (Busch, 2016). Programatik reklamcılık; reklamverenlere kimi hedefledikleri, hangi medyada ve bunun ne zaman gerçekleştiği konusunda daha fazla ayrıntı sunar. Bunun temelini oluşturan yeni teknolojiler ve uygulamalardır. Bunlar, otomasyon, daha sofistike veri toplama ve işleme ve daha fazla medya içeriği ve izleyici pazarları ile karakterize edilir. Otomatikleştirilmiş 
ve kendi kendine yönetilen bir pazarda baş döndürücü hızlarda sağlanan yüksek frekanslı ticaret ve marjinal kazanç potansiyeli ile birlikte reklam sektörünün doğasında köklü değişiklikler meydana gelmiştir (McStay, 2017).

Sayısallaştırmanın yanı sıra, veri toplama ve yönetiminin otomasyonunu ele alan teknolojilerin benimsenmesi, pazar araştırması etiğinde tartışılan sorunların yanı sıra büyük verinin reklam sektörüne etkileri, daha geniş tartışmaları ve yepyeni bir etik problemleri ve zorluklar yelpazesini ortaya çıkarmıştır (Nunan ve Di Domenico, 2013). Bunlarla birlikte, tüketicilerin kişisel verilerin yakalanması ve kullanılması konusundaki hassasiyeti, daha fazla veriye erişimin sınırlı hâle geldiği noktaya yükselebilir. Bu, belki de tüketici lobi grupları veya diğer siyasi baskılar tarafindan motive edilen mevzuat değişiklikleri yoluyla gerçekleşebilir. Aynı zamanda, programatik reklamcılık kullanan ve bir araya gelerek geniş veri kümelerini kullanan kuruluşların tüketiciler tarafindan dışlanmasına yol açan alternatif bir şekilde de ortaya çıkabilir (örneğin, tüketicilerle anlaşmazlığa düştüğü düşünülen kuruluşlardan kaçınmak için kopyalanan bir hareket, çevre ile ilgili değerler, vd.) (White ve Samuel, 2019). Dijital gizlilik sorunları, veriye dayalı teknolojiler hakkında daha geniş bir tartışmanın parçasıdır. Bir bakıma, dijitalleşme ve otomasyon, reklamcılığa bir dizi etik problemler, zorluklar ve pazarlama etiğinde bilgi yönetimi ile ilgili yeni bir kültür getirmiştir (Nunan ve Di Domenico, 2013).

Geçtiğimiz yıllarda yaşanan Facebook veri ihlali skandalından sonra kullanıcıların çevrim içi gizlilik endişeleri artı̧̧ göstermiştir. Hükûmetler de bunun farkına vararak kişisel verilerin korunmasına ilişkin katı düzenlemeler getirmişlerdir. Dijital pazarlama alanında AB'nin Genel Veri Koruma Yönetmeliği, şirketleri veri hijyeni ve güvenliğine daha fazla önem vermeye zorlamıştır. Aynı şekilde 2016 yılında ülkemizde yürürlüğe giren 6698 sayılı Kişisel Verilerin Korunması Kanunu (KVKK) ve bu kanun çerçevesinde oluşturulan ikincil mevzuat ile ülkemizde veri ihlalleri konusunda hukuki altyapı oluşturulmuştur. Bu teknolojilerin üretim merkezi olan Kaliforniya'da 2020 yılı başında Kaliforniya Tüketici Gizlilik Yasası yürürlüğe girmiştir. Dolayısıyla bu süreçte tüm reklamverenlerin bu düzenlemelere uyması ve yeni stratejiler geliştirmek için yatırım yapmaları gerekecektir. Ayrıca veri ihlalleri ve kişisel verilerin kötüye kullanımıyla ilgili olarak medyada artan kapsam ve dünya çapında gizlilik düzenlemelerinin yaygınlaşması sayesinde tüketiciler bu konuda yavaş da olsa bilinçlenmeye başlamıştır.

Tanımlama, hedefleme ve ölçmeyi daha da zorlaştırmaya devam edecek ve üçüncü taraf çerezleri ve takibi konusunda daha fazla kısıtlama getirecek olan yeni yasal değişikliklerin dijital pazarlama ortamına tam etkisini değerlendirmek için henüz çok erken. Bunula birlikte Kaliforniya Tüketici Gizliliği Yasası (CCPA) gibi dü- 
zenlemeler ile getirilen tarayıcı gizlilik ayarları ve diğer gizlilik değişiklikleri, dijital pazarlama ekosistemini gelecekte daha fazla etkileyecektir (Fisher, 2019). Etkisiz geleneksel reklam planlama yöntemleri, dijital medyanın artan reklam doygunluğu ve reklamcılık sektöründeki dijital oyuncuların yıkıcı etkisi, günümüz internetinde reklamcılık için yeni yöntem ve araçlara ihtiyaç yaratmıştır. Programatik reklamcılık bugün yeni çevrim içi reklamcılık ortamının en verimli otomasyon biçimlerinden biri olarak kabul edilmektedir ve reklamcılık pazarında hâkimiyeti ele almaktadır. Bununla birlikte, ulusal ve bölgesel ölçekte uygulama düzeyi ve bu yeni teknolojinin uygulanmasından elde edilen etik çıkarımlar ile ilgili hâlâ bazı önemli, ele alınmamış sorular bulunmaktadır (Martinez-Martinez, vd., 2017).

Dijital reklamcılık, büyük verinin yönetimi ile birlikte son dönemde yıkıcı bir değişim yaşamaktadır. Şirketlerin ve markaların tüketicileri hedefleme, tercihlerini ve davranışlarını kaydetme, onları ikna etme ve tüketici karar sürecine müdahale etme şekli dramatik bir şekilde değişmiş durumdadır. Özellikle tüketicilerin çevrim içi davranışından elde edilen büyük veri, pazarlamacılara programatik reklamcılık aracılığıyla uygun maliyetli ve büyük bir hassasiyetle optimize edilmiş kampanyalar oluşturma firsatlarını artırmıştır. Ekonomik, politik ve kültürel yaşamın diğer pek çok sektörü gibi, medya endüstrileri de büyük verinin sağladığı olanaklardan etkilenmiş durumdadır. Medya endüstrileri, belki de diğer birçok endüstri sektöründen daha fazla, büyük verilerin potansiyelini yakalamak ve kullanmak için iyi konumlandırılmıştır (Napoli, 2016).

Sonuç olarak yeni medya, reklam sektöründe eskiden kullanılmayan metot ve formların hayata geçirilmesini sağlamış, anlık verimlilik analizi, yüksek performans, hız ve etkileşim gibi kolaylıklar sağlamıştır. Ancak dijital medya reklamcılığı ile reklamın nerede yapıldığı değil, kimin ne tür tüketici verilerine ulaştı̆ı ve bu verilere göre nasıl hedef alınabileceği ile ilgili sorular ortaya çıkmıştır. Dijital medya araçları ile her tüketiciye özel, kişiselleştirilmiş, tüketicinin bulunduğu yere yönlendirilebilen, gerçek zamanlı reklamlar gösterilmesi imkânı yaratılmıştır. Dolayısıyla geleneksel reklam süreçleri derinden etkilenmiş ve doğrusal kampanyalar oluşturmanın yerini pek çok kampanya alternatifinin eş zamanlı yapılabildiği yeni bir reklam türü doğmuştur. Yeni medyayı kullanarak tüketicilere anında ulaşmak için tasarlanan programatik reklamcılık doğru kişilere, doğru zamanda ve doğru şekilde ulaşmak isteyen şirketler için vazgeçilmez bir araç hâline gelmiştir. Tüketicilerin yeni medyada geçirdikleri sürenin her geçen gün arttğı düşünüldüğünde, analiz edilecek büyük veri hacmi de artmaktadır. Bu nedenle, programatik reklamcılığın büyümeye devam etmesi kaçınılmazdır. 
Gelişmiş hedefleme seçenekleri sunan ve artk hayatımıza tamamen giren programatik reklamcılık gibi veriye dayalı dijital sistemlerin kişisel verilere erişimini engellemek veya sınırlandırmak tamamen tüketicinin elindedir. Her ne kadar mevzuatla korunan alanlar olsa da dijital medyadaki gizlilik ihlallerinden ve bunların olası olumsuz sonuçlarından kaçınabilmek için her düzeyde farkındalığın artırılmasına ve dijital tüketicilerin reklam okuryazarlığı çerçevesinde bilgilendirilmesine intiyaç bulunmaktadır.

\section{Kaynakça}

Acquisti, A. (2009). Nudging Privacy: The Behavioral Economics of Personal Information. IEEE Security \& Privacy. 7 (6), 82-85.

ANA (Association of National Advertisers). (2014). The Bot Baseline: Fraud in Digital Advertising. https://www.whiteops.com/hubfs/ANA_WO_Bot_Baseline_2014-1.pdf Erişim: 06.02.2021

Baker, S. (2009). Learning and Profiting from Online Friendships. BusinessWeek, https:// www.bloomberg.com/news/articles/2009-05-21/learning-and-profiting-from-online-friendships Erişim: 25.01.2021

Busch, O. (2016). The Programmatic Advertising Principle. Programmatic Advertising: The Successful Transformation to Automated, Data-Driven Marketing in Real-Time, Springer, 3-16.

Carlson, D. (2005). The News Media's 30-Year Hibernation. Nieman Reports, 59 (3), 68-71.

Davies, J. (2019). Data privacy-first advertising is here: Here are the winners and losers. https://digiday.com/media/winners-losers-data-privacy-first-advertising/ Erişim: 01.02.2021

Deighton, J. ve Kornfeld, L. (2009). Interactivity's Unanticipated Consequences for Marketers and Marketing. Journal of Interactive Marketing, 23, 4-10.

Digitaltalks (2016). https://www.digitaltalks.org/2016/05/17/gorsel-pazarlama-lokasyon-bazli-hedeflemenin-gelecegi/ Erişim: 31.01.2021

Fisher, L. (2019). Digital Marketing in Today's Privacy-Conscious World. https://www. emarketer.com/content/digital-marketing-in-todays-privacy-conscious-world Erişim: 01.02.2021

Gertz, O. ve McGlashan, D. (2016). Consumer-Centric Programmatic Advertising. Programmatic Advertising: The Successful Transformation to Automated, Data-Driven Marketing in Real-Time, Oliver Busch (Ed.), Springer, 55-86.

Google Digital Garage (2021). The Fundamentals of Digital Marketing. E-Ders. https://learndigital.withgoogle.com/digitalgarage/course/digital-marketing Erişim: 23.01.2021

Gonzalvez, J.C. ve Mochon, F. (2016). Operating an Advertising Programmatic Buying Platform: A Case Study. International Journal of Interactive Multimedia and Artificial Intelligence, Vol. 3, 6-15. 
Hennig-Thurau, T., Malthouse, E. C., Friege, C., Gensler, S., Lobschat, L., Rangaswamy, A. ve Skiera, B. (2010). The Impact of New Media on Customer Relationships. Journal of Service Research, 13(3), 311-330.

Herdman, E.A. (2006). Guidelines for Conducting a Literature Review and Presenting Conference Papers. Journal of Education and Research in Nursing . 3 (1), 2-4.

Hudson, S., Huang, L., Roth, M.S. ve Madden, T. J. (2016). The Influence of Social Media Interactions on Consumer-Brand Relationships: A Three-Country Study of Brand Perceptions and Marketing Behaviors. International Journal of Research in Marketing, 33(1), 27-41.

IAB (Interactive Advertising Bureau). (2021). https://www.iab.com/insights/ Erişim: 31.01.2021

Koç, F., Çetin, O. ve Alnıaçık, Ü. (2016). Reklam Etiği: Televizyon Reklamlarında Cinselliğin Kullanımı. Global Business Research Congress (GBRC), Vol.2, 692-702.

Kotler, P., Kartajaya, H. ve Setiawan, I. (2017). Marketing 4.0: Moving from Traditional to Digital, First Edition, New Jersey: John Wiley \& Sons.

KVKK (Kişisel Verileri Koruma Kurumu). (2019). 2019 Yılı Faaliyet Raporu. Ankara.

Martinez-Martinez, I.J., Aguado, J.M. ve Boeykens, Y. (2017). Ethical implications of digital advertising automation: The case of programmatic advertising in Spain. El Profesional de la Informacion, 26(2), 201-210.

McStay, A. (2017). Micro-Moments, Liquidity, Intimacy and Automation: Developments in Programmatic Ad-tech. In G. Siegert, M. B. Rimscha, \& S. Grubenmann (Eds.), Commercial Communication in the Digital Age. 143-159.

Mukherjee, A., Sundarraj, R.P. ve Dutta, K. (2015). An Online Algorithm for Programmatic Advertisement Placement in Supply Side Platform of Mobile Advertisement. Pacific Asia Conference on Information Systems (PACIS) 2015 Proceedings.

Napoli, P.M. (2016) Special Issue Introduction: Big Data and Media Management, International Journal on Media Management, 18 (1), 1-7.

Nunan, D. ve Di Domenico, M.L. (2013). Market Research and the Ethics of Big Data. International Journal of Market Research. 55 (4), 505-520.

Ponemon Institute (2016). Data Risk in the Third-party Ecosystem. Research Report. https://www.ponemon.org/research/ponemon-library/privacy/ Erişim: 29.01.2021

Rainie, L. ve Duggan, M. (2016). Privacy and Information Sharing. Pew Reseach Center. https://www.pewresearch.org/internet/2016/01/14/privacy-and-information-sharing/ Erişim: 28.01.2021

Reach First (2021). Understanding Digital Consumers. https://www.reachfirst.com/understanding-digital-consumers/ Erişim: 06.02.2021

Watts, M. (2016). Programmatic advertising: Shaping consumer behavior or invading consumer privacy? Undergraduate Distinction Thesis. Ohio State University. http://kb.osu.edu/dspace/handle/1811/76764 Erişim: 25.01.2021

White, G.R.T. ve Samuel, A. (2019). Programmatic Advertising: Forewarning and avoiding hype-cycle failure. Technological Forecasting and Social Change, Volume $144,157-168$. 
